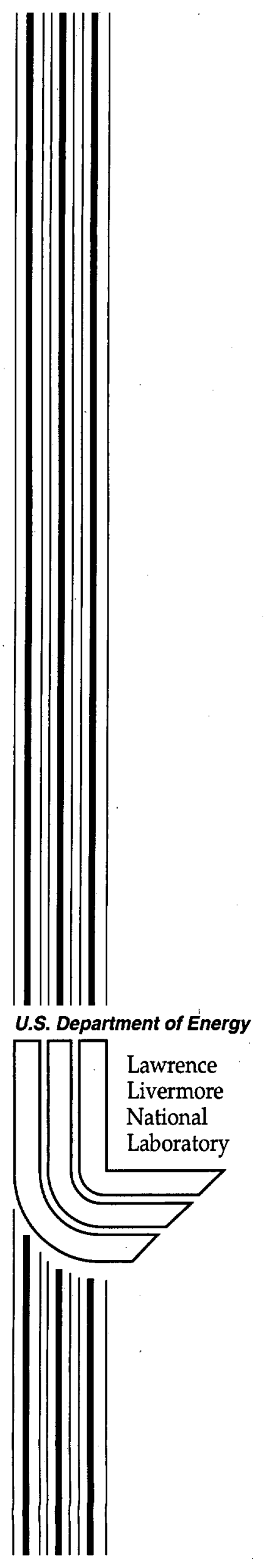

UCRL-ID-145419

\title{
A New IAB Iron Meteorite From China
}

K.V. Ponganis, B. Lavielle, B. Spettel, V.F. Buchwald, K. Nishiizumi, M.W. Caffee, K. Marti

\section{March 30, 2001}




\section{DISCLAIMER}

This document was prepared as an account of work sponsored by an agency of the United States Government. Neither the United States Government nor the University of California nor any of their employees, makes any warranty, express or implied, or assumes any legal liability or responsibility for the accuracy, completeness, or usefulness of any information, apparatus, product, or process disclosed, or represents that its use would not infringe privately owned rights. Reference herein to any specific commercial product, process, or service by trade name, trademark, manufacturer, or otherwise, does not necessarily constitute or imply its endorsement, recommendation, or favoring by the United States Government or the University of California. The views and opinions of authors expressed herein do not necessarily state or reflect those of the United States Government or the University of California, and shall not be used for advertising or product endorsement purposes.

This is a preprint of a paper intended for publication in a journal or proceedings. Since changes may be made before publication, this preprint is made available with the understanding that it will not be cited or reproduced without the permission of the author.

This report has been reproduced directly from the best available copy.

Available electronically at http://www.doe.gov/bridge

Available for a processing fee to U.S. Department of Energy and its contractors in paper from

U.S. Department of Energy

Office of Scientific and Technical Information

P.O. Box 62

Oak Ridge, TN 37831-0062

Telephone: (865) 576-8401

Facsimile: (865) 576-5728

E-mail: reports@adonis.osti.gov

Available for the sale to the public from

U.S. Department of Commerce

National Technical Information Service

5285 Port Royal Road

Springfield, VA 22161

Telephone: (800) 553-6847

Facsimile: (703) 605-6900

E-mail: orders@ntis.fedworld.gov

Online ordering: http://www.ntis.gov/ordering.htm

OR

Lawrence Livermore National Laboratory

Technical Information Department's Digital Library

http://www.llnl.gov/tid/Library.html 
A NEW IAB IRON METEORITE FROM CHINA. K.V. Ponganis ${ }^{1}$, B. Lavielle ${ }^{2}$, B. Spettel ${ }^{3}$, V.F. Buchwald ${ }^{4}$, K. Nishiizumi ${ }^{5}$, M.W. Caffee ${ }^{6}$, and K. Marti ${ }^{1},{ }^{1}$ Dept. of Chemistry \& Biochemistry, UCSD, La Jolla, CA 920930317, USA (kpongani@ucsd.edu), ${ }^{2}$ Laboratoire de Chimie Nucléaire Analytique et Bioenvironnementale, U.M.R. 5084 of CNRS, University of Bordeaux I, BP120, Le Haut Vigneau, 33175 Gradignan Cedex, France, ${ }^{3}$ Max-PlanckInstitute für Chemie, Postfach 3060, D-55020 Mainz, Germany, ${ }^{4}$ Ingeborgvej 4, DK-2920 Charlottenlund, Denmark, ${ }^{5}$ Space Sciences Laboratory, UC Berkeley, Berkeley, CA $94720-7450$, USA, ${ }^{5}$ Center for Accelerator Mass Spectrometry, Lawrence Livermore National Laboratory, Livermore, CA 94550, USA.

Introduction: Dr. W. Wei, at UCSD, provided our laboratory with chips from a suspected iron meteorite. The mass $(>10 \mathrm{~kg})$ was found approximately $8 \mathrm{~km}$ northwest of Zhongshan in Guangxi province by a farmer in his fields. This mass has now been identified as an IAB iron meteorite (provisional name Zhongshan \#1) based on its composition, $\mathrm{N}$ signature, and petrographic analysis. A second chip from a much larger mass (Zhongshan \#2), still in the ground, was recently made available and work is in progress on it, but not reported.

Elemental Composition: A $65 \mathrm{mg}$ sample of Zhongshan \#1 was analyzed by INAA at the Max Planck Institute in Mainz. Results are summarized in Table 1. The concentration of diagnostic elements for iron meteorites, such as $\mathrm{Ni}, \mathrm{Ga}, \mathrm{Ge}$, and platinum group metals, are consistent with the IAB/IICD group (see Figure 1). [1]

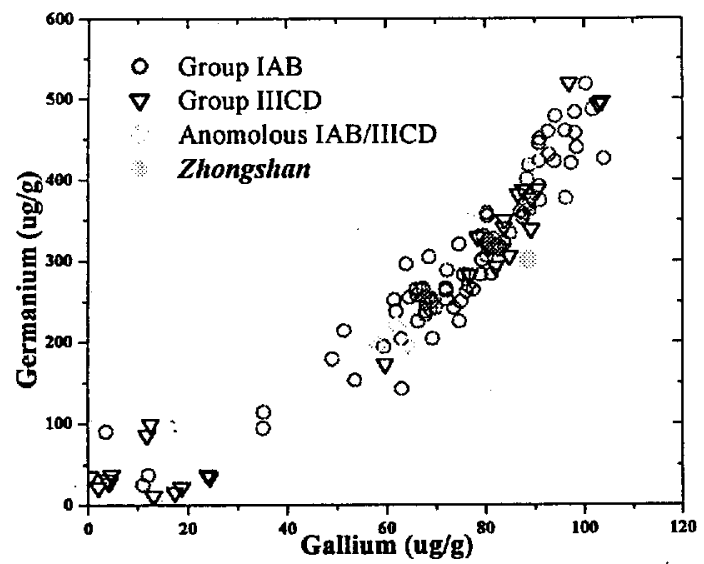

Figure 1. Position of Zhongshan sample \#1 in a $\mathrm{Ge}$ vs. Ga plot for the IAB/IIICD iron meteorites. Group data is from $\lceil 11$.

Isotopic Signatures of $\mathrm{N}$ and Xe: Both $\mathrm{N}$ and $\mathrm{Xe}$ isotopic signatures were done at UCSD on Zhongshan sample \#1. The step-release profile of $N$ is shown in Figure 2. In iron meteorites the signature of indigenous $\mathrm{N}$ is highly variable and can be used for classification. [2,3] Nitrogen isotopic analysis indicated that the $N$ step-release profile in this sample is consistent with the IAB/IIICD group, [4] although the total $\mathrm{N}$ amounts are extremely small $(0.57 \mathrm{ppm})$. The average $\delta^{15} \mathrm{~N}$ for steps $1400^{\circ} \mathrm{C}$ to $1600^{\circ} \mathrm{C}$ is $-(78 \pm 25) \%$. There is a different signature for the $900{ }^{\circ} \mathrm{C}$ to $1000^{\circ} \mathrm{C}$ temperature steps (avg. $\delta^{15} \mathrm{~N}=-(40 \pm 7) \%$ ), suggesting the presence of at least two $\mathrm{N}$ sources in the sample. The Xe data can be used to trace the presence of inclusions like silicates. [5] The ${ }^{129} \mathrm{Xe} /{ }^{132} \mathrm{Xe}$ ratio $(1.38 \pm 0.04)$ shows a ${ }^{129} \mathrm{Xe}$ excess for $1200^{\circ} \mathrm{C} \leq \mathrm{T} \leq 1600^{\circ} \mathrm{C}$, which is consistent with the presence of minor inclusions.

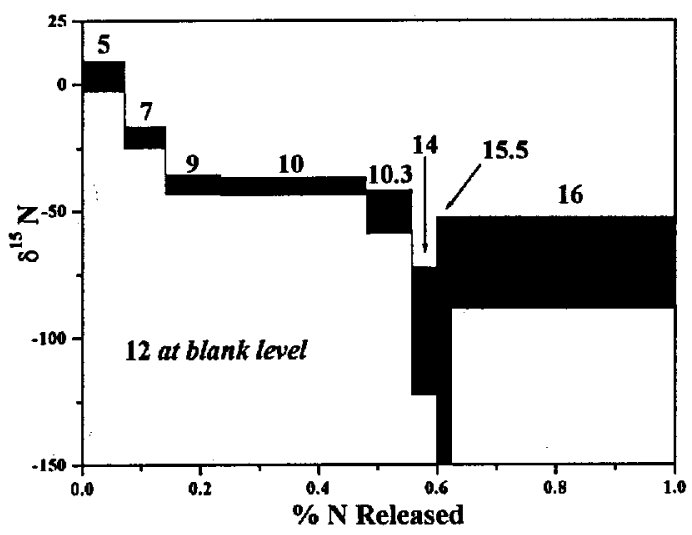

Figure 2. The stepwise pyrolysis of the Zhongshan iron sample \#1. Temperature is in hundreds of ${ }^{\circ} \mathrm{C}$. The large uncertainties for the steps $\geq 1200^{\circ} \mathrm{C}$ reflect the low concentrations of $\mathrm{N}$ and the variable and large blank corrections.

Cosmogenic Components: An analysis of $\mathrm{He}, \mathrm{Ne}$, and Ar on Zhongshan \#1 was done at Laboratoire de Chimie Nucléaire Analytique et Bioenvironnementale (see Table 2). The observed ratio ${ }^{36} \mathrm{Ar} /{ }^{38} \mathrm{Ar}$ of 0.6194 represents a spallation component from a shielded location. The ${ }^{4} \mathrm{He}^{21} \mathrm{Ne}$ ratio $(374 \pm 17)$, the shielding parameter, supports this conclusion.

We can only estimate the cosmic-ray exposure (CRE) age for this meteorite since work on the ${ }^{36} \mathrm{Cl}$ concentration is still in progress. However, assuming a simple exposure history and based on the Ar concentration and on the ${ }^{4} \mathrm{He} /{ }^{21} \mathrm{Ne}$ ratio, the ${ }^{36} \mathrm{Cl}$ value should be $\leq 11 \mathrm{dpm} / \mathrm{kg}$. (see Figure 3). Using a ${ }^{36} \mathrm{Ar}$ value of $11.38 \times 10^{-8} \mathrm{~cm}^{3} \mathrm{STP} / \mathrm{g}$, the CRE age is estimated to be $\geq 440 \mathrm{Ma}$

Petrographic Analysis: A sample of Zhongshan \#1 was studied at the Geologisk Museum, Copenhagen. A chip was polished, and then, etched lightly with $1 \%$ Nital before analysis.

The bulk of the specimen is kamacite, with a bandwidth estimated at $(11.9 \pm 0.3) \mathrm{mm}$. The kamacite, which is rich in Neumann bands, is penetrated by a multitude of shear zones that bend the Neumann bands and shear 


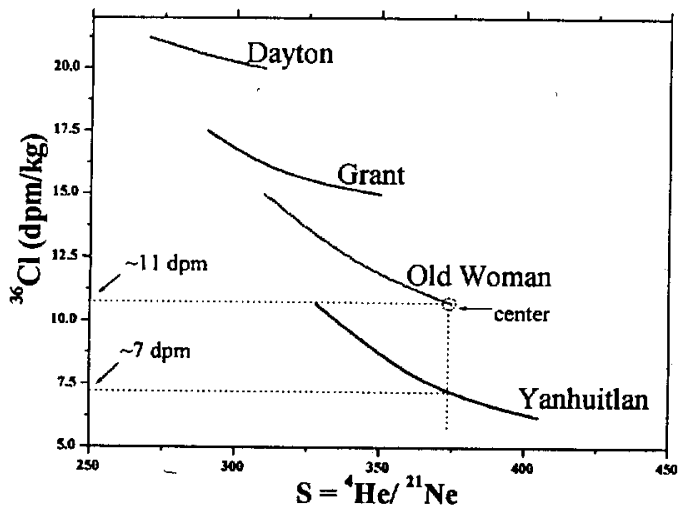

Figure 3. Meteorite Shielding: Size vs. Depth. Using the shielding parameter $S=374$ and the ${ }^{36} \mathrm{Cl}$ profiles from large irons, the expected ${ }^{36} \mathrm{Cl}$ concentration is $\leq 11 \mathrm{dpm} / \mathrm{kg}$. The CRE age is calculated using the following equation: Tc (in Ma) $=427 \times\left[{ }^{36} \mathrm{Ar}\right] /\left[{ }^{36} \mathrm{Cl}\right]$, where $\left[{ }^{36} \mathrm{Ar}\right]$ is in $10^{-8} \mathrm{~cm}^{3} \mathrm{STP} / \mathrm{g}$ and $\left[{ }^{36} \mathrm{Cl}\right]$ is in dpm/kg. [6] The estimated CRE age is $\geq 440$ $\mathrm{Ma}$, based on Old Woman (recovered mass $2753 \mathrm{~kg}$ ) and Yanhuitlan (recovered mass $421 \mathrm{~kg}$ ) systematics.

the minerals. The Vickers hardness ( $200 \mathrm{~g}$ load) of the kamacite is: $198-199-228-232-233-245$. These values are high for kamacite, but are due to the significant cold deformations observed in the microstructure.

Taenite is present as up to $0.06 \mathrm{~mm}$ wide lamellae, alternating in bluish and brownish colors, suggesting a submicroscopic two-phased structure (probably tetrataenite and associated structures). Three or four plessite fields of the comb plessite variety are present, the largest field being $3 \times 1.5 \mathrm{~mm}$. The bulk Ni $(6.6 \%)$ seems a little low for the average structure observed.

Schreibersite is abundant as grain boundary crystals (up to $0.08 \mathrm{~mm}$ wide). Rhabdites are very common, but most are $<0.02 \mathrm{~mm}$ across. Sub-boundaries of the kamacite are decorated with $0.002 \mathrm{~mm}$ crystals, probably of phosphides, but possibly supplemented by some carbides. Both schreibersite and rhabdites are severely sheared and displaced. Terrestrial corrosion has had easy access along the grain boundaries with sheared schreibersite, both because of the capillary action and because of the $\mathrm{Ni}$ gradient in kamacite adjacent to schreibersite.

The fusion crust and the heat-affected $\alpha_{2}$ zone have been lost by weathering. However, heavy deformation and shearing has generated locally sufficient heat $\left(>800^{\circ} \mathrm{C}\right.$ for a short period of time) to transform kamacite to serrated $\alpha_{2}$ grains and remove the Neumann bands. This friction re-heating may have occurred when the meteorite suffered a violent split-up upon entering the Earth's atmosphere. The deformation of the present specimen indicates that it is only a fragment of a bigger shower, consistent with the find nearby of a much larger mass of iron ( $>1$ ton). The absence of cohenite, graphite, and troilite may be due to the fact that the analysis was performed on a very small, unrepresentative fragment.

Conclusion: Preliminary $\mathrm{N}$ isotopic analysis on Zhongshan sample \#1 suggested that the iron mass might be a IAB/IIICD type. Petrographic inspection and INAA analysis has verified that this sample is a typical member of the coarse octahedrites, of the resolved chemical group IAB. Zhongshan \#1 was wellshielded (see Figure 3). Its estimated CRE age is $\geq 440$ Ma. Determination of the radionuclides and noble gases on Zhongshan sample \#2 (in progress) will give useful information on the exposure and shielding history of the meteoroid and its possible atmospheric break-up.

Acknowledgements: We are grateful to Dr. W. Wei at UCSD for bringing the meteorite to our attention and to Dr. J. Zipfel at Max-Planck-Institute für Chemie for her help in this work.

References: [1] Choi, B.G., et al., (1995) Geochimica Et Cosmochimica Acta 59: 593-612. [2] Prombo, C.A. and Clayton, R.N., (1993) Geochimica et Cosmochimica Acta 57: 3749-3761. [3] Franchi, I.A., et al., (1993) Geochimica et Cosmochimica Acta 57: 3105-3121. [4] Ponganis, K.V., et al., (2000) Meteoritics and Planetary Science 35 (Supplement): A128-129. [5] Ponganis, K.V. and Marti, K., (2000) LPSC XXXI: [6] Lavielle, B., et al., (1999) Earth and Planetary Science Letters 170: 93-104.

Table 1. Trace elements of Zhongshan \#1 sample. Fe is $91.94 \%$ (3\% error) and $\mathrm{Ni}$ is $6.60 \%$ ( $4 \%$ error), by mass.

\begin{tabular}{ccc|ccc|ccc}
\hline Element & ppm & \% error & Element & ppm & \% error & Element & ppm & \% error \\
\hline $\mathrm{Co}$ & 4330 & 3 & $\mathrm{Mo}$ & 8.20 & 7 & $\mathrm{Re}$ & 0.200 & 5 \\
$\mathrm{Cu}$ & 136 & 4 & $\mathrm{Ru}$ & 5.70 & 15 & $\mathrm{Os}$ & 2.90 & 7 \\
$\mathrm{Ga}$ & 88.6 & 3 & $\mathrm{Pd}$ & 3.60 & 15 & $\mathrm{Ir}$ & 2.34 & 3 \\
$\mathrm{Ge}$ & 301 & 7 & $\mathrm{Sb}$ & 0.390 & 10 & $\mathrm{Pt}$ & 7.20 & 7 \\
$\mathrm{As}$ & 11.9 & 4 & $\mathrm{~W}$ & 1.01 & 5 & $\mathrm{Au}$ & 2.22 & 3 \\
$\mathrm{Se}$ & $<4$ & - & & & & & & \\
\hline
\end{tabular}

Table 2. Cosmogenic noble gas concentrations (in $10^{-8} \mathrm{~cm}^{3} \mathrm{STP} / \mathrm{g}$ ) and ratios for the Zhongshan \#1 sample.

\begin{tabular}{cccccccccc}
\hline & ${ }^{4} \mathrm{He}$ & ${ }^{21} \mathbf{N e}$ & ${ }^{36} \mathbf{A r}$ & ${ }^{38} \mathbf{A r}$ & ${ }^{3} \mathbf{H e} /{ }^{4} \mathbf{H e}$ & ${ }^{36} \mathbf{A r} /{ }^{38} \mathbf{A r}$ & ${ }^{4} \mathbf{H e} /{ }^{21} \mathbf{N e}$ & ${ }^{4} \mathbf{H e} /{ }^{38} \mathbf{A r}$ & ${ }^{21} \mathbf{N e} /{ }^{38} \mathbf{A r}$ \\
\hline value & 1120 & 2.995 & 11.38 & 18.37 & 0.2435 & 0.6194 & -374 & 61.0 & 0.1631 \\
error $(\mathbf{2 \sigma})$ & 37 & 0.093 & 0.19 & 0.29 & 0.0040 & 0.0037 & 17 & 2.3 & 0.0057 \\
\hline
\end{tabular}

This work was performed under the auspices of the U.S. Department of Energy by the University of California, Lawrence Livermore National Laboratory under Contract No. W-7405-Eng-48. 